\title{
Spatial Analysis of Gully Erosion Control Measures in Gombe Town, Gombe State Nigeria
}

\author{
Lazarus Abore Mbaya \\ Department of Geography, Gombe State University \\ lazarusambaya@yahoo.com
}

\begin{abstract}
The performance of gully erosion control measures in Gombe metropolis is presented. This paper aimed at assesses the spatial distribution of gully erosion control measures in Gombe town since 2004 to 2015. The objectives of the research are to identify the spatial distribution of gullies in Gombe town and to analyze the length of gullies so far checked or controlled. High resolution images of the study area (Quick bird 2004 and 2015) were acquired for GIS analysis and ground truth measurement. Information gathered from field and image digitization was used to determine increase in the size and length of gully erosion from 2004 to 2015. In order to identify recently developed gullies, ArcGIS software was used to perform spatial analysis. Result of the study revealed that most of the previous uncontrolled or partially checked gullies have increased in length to $131.02 \mathrm{~km}$ as against the 121.50 $\mathrm{km}$ in 2003. This represents an increase of $9.72 \mathrm{~km}$ (7.42\%) over the 13 years period or about 75 metres annual increase in gully length. The analysis further revealed that there were 615 first order gullies representing $62 \%$ second order has 173 gullies or $18 \%$, third order gullies has 89 in number and represent $12 \%$, the fourth order has a total of 51gullies in number representing $5 \%$, the fifth order consist of 30 gullies or $2 \%$ and the sixth order number which is the main gully has 11 in number representing $1.0 \%$ respectively. Out of the $131.02 \mathrm{~km}$ length of gully erosion inventory in Gombe town in 2015 only $41.32 \mathrm{~km}$ length has been controlled and $35.92 \mathrm{~km}$ under engineering method representing $87 \% ; 5.1 \mathrm{~km}(12.3 \%)$ length of vegetation and only $0.3 \mathrm{~km}$ under stone wall control measures out of the total $41.32 \mathrm{~km}$ length of the three methods of control measures under study. It is therefore suggested that apart from government efforts other stakeholders should be encourage and participate in gully erosion control especially adoption of vegetation method which is affordable, accessible and acceptable.
\end{abstract}

Keywords: Gullies, Control, Spatial, Vegetation, Gombe

\section{Introduction}

The formation of gullies has become one of the greatest environmental disasters facing residents of Gombe towns (Lazarus, et al. 2012). This town is fast becoming hazardous for human habitation. Hundreds of people are directly affected every year and have to be re-located. Large areas of agricultural lands are becoming unsuitable for cultivation as erosion destroys farmlands and lowers agricultural productivity. The demographic increase and various infrastructural development meant to improve the standard of living of the people has on the other hand devastated the environment especially where uncoordinated development is taking place. Each yearly rainy season is accompanied by increases in gully length, depth and width. The incidents of gully have caused much concern to successive governments of Gombe state and other stakeholders where concerted efforts of control DOI: 10.14738/aivp.54.3343 
Lazarus Abore Mbaya; Spatial Analysis of Gully Erosion Control Measures in Gombe Town, Gombe State Nigeria, Advances in Image and Video Processing, Volume 4 No 5, August (2017); pp: 17-28

measures were taken each year. Various methods adopted by government and residents of Gombe town in gully erosion control measures include engineering, tree planting or vegetation, stone wall sand bag and diversion of runoff. However, the control measures has not kept pace with rate of gully expansion or growth, as some of these measures have been fully or partially successful while others have failed, partly due to inadequate fund to adopt holistic method of control measure that stand the test of time.

This paper aimed at assesses the spatial distribution of gully erosion control measures in Gombe town since 2003 to 2016. The objectives of the research are to identify the spatial distribution of gullies in Gombe town; to analyze the length of gullies so far checked or controlled; and to assess the lengths of gullies unchecked in the study area. It is hoped that the results presented herein would be of interest to planners and designers of gully control measures in Nigeria and elsewhere where similar gully problems occur.

\section{Methodology}

\subsection{The study Area}

Gombe metropolis is located between latitude $10^{0} 0^{1} \mathrm{~N}$ to $10^{0} 26^{1} \mathrm{~N}$ and longitude $11^{0} 01^{1} \mathrm{E}$ and $11^{0} 19^{1} \mathrm{E}$. It shares a common boundary with Akko L.G.A on the south Yalmaltu-Deba to the East and Kwami to the North. It occupies a total land area of about $56 \mathrm{~km}^{2}$. Based on koppen's (1929) classification, Gombe is within the savannah climate (AW) type of climate. It is a reasonably wet and dry area, having a mean annual rainfall and temperature of $850 \mathrm{~mm}$ and $28^{\circ} \mathrm{C}$ respectively.

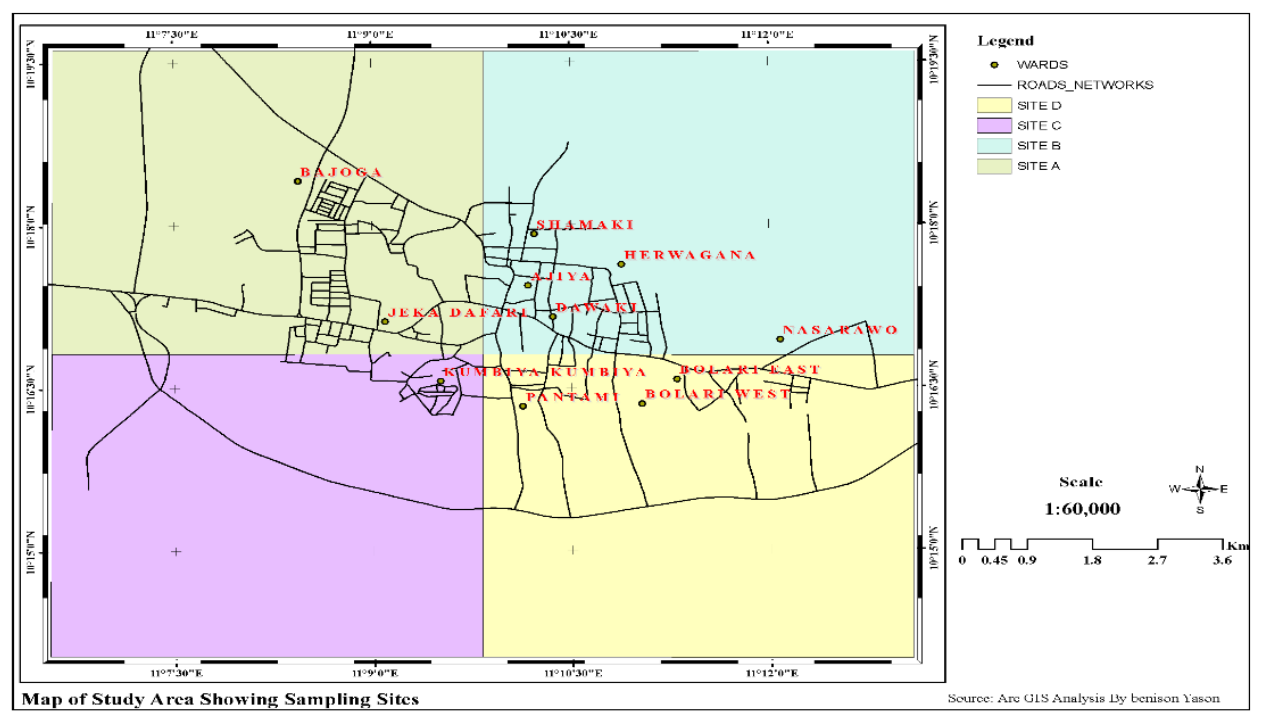

Figure 1: Study area, Gombe Metropolis. Source: GIS analysis/Field work, 2016.

However annual rainfall is concentrated between the month of June to September with its maximum in July and August. There is little information on the rainfall intensity. However, a heavy rainfall especially in July and August is associated with storms of high intensity accelerating gully erosion (Balzerek, et al., 2003).

Gombe town is underlain by the Gombe Sand stone and Pindiga formation. There are estauritic gift Sandstone; Silt stone, shale and Iron stone. There are also quite trace of marine shale's and mud stone that belong to the Pindiga shale and Yolde formation respectively that belong to the Paleocene and Cenozoic ages. Gombe town is generally a low lying region except for the high land areas such as the Gombe hill and the Liji hills (Arabi et al., 2009). 
The soil of Gombe is that of tropical ferruginous type. They are dark grey in color and have PH value ranging from 4 to 6 depending on the location. The soil are intensively formed as a result of incomplete weathering of the basement rock traditionally and management practices have however made them susceptible to erosion and reduced, then water holding capacity.

The vegetation of Gombe area can be described as Sudan savannah with open grassland and shrubs which dries up during the dry season. The natural vegetation has been greatly affected and modified over most of the areas by human activities such as overgrazing, bush burning, construction and agriculture. The predominant tree species consist of Afzillia Africana, parkai bigiobosa, Adamsonia digitata and tamarindus indica, instead of continuous grass cover, the vegetation has been cleared in places for farm and building.

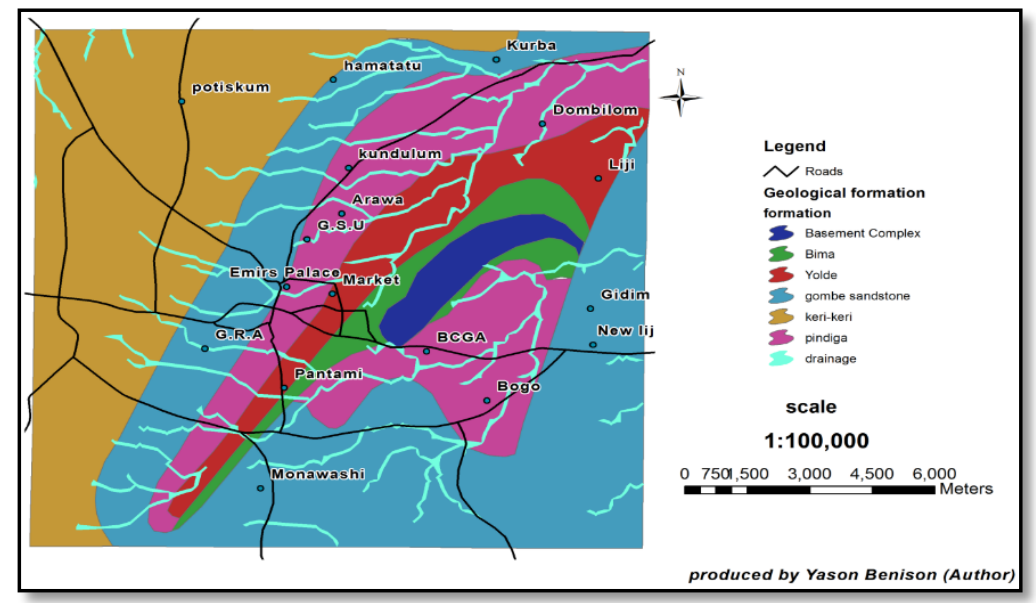

Figure 2: Geological map of Gombe metropolis

The pattern of population growth of Gombe town was slow from 1900 to 1952 (300 to 18,500 people) while; from 1964 to 1991 the population growth has increased tremendously from 47,000 to 138,000. However, from the year 1996, when Gombe became the state capital, there was a noticeable sharp increase in population from 169, 894 (1996) to 219,946 in 2006 (Tiffen, 2006) and 312,467 in 2010 (National Population Commission, 2007).

\subsection{Materials and Methods}

A methodological frame work in the context of GIS, remote sensing and related techniques was employed, using both spatial and non-spatial datasets to the study of gully erosion phenomenon in the study area. Datasets for this study include both spatial and the non spatial data, some of which can be categories into primary and secondary data. The primary data are information that consists of information gathered from the field investigation, measurement and observation. High resolution images of the study area (Quick bird 2004 and 2015) were acquired for GIS analysis, this included vector and raster formats generated from on-screen digitization and classification while the secondary are existing materials to be collected from literature reviews and others materials.

Information gathered from field and image digitization was used to determine increase in the size and length of gully erosion from 2004 to 2015. In other to identify recently developed gullies, ArcGIS software was used to perform spatial analysis; while Excel spread sheet provide the platform for database development for subsequent transfer onto ArcGIS platform in a loose coupling approach.

The collected images are pre-processed by radiometric or geometric corrections. Radiometric corrections include correcting the data for sensor irregularities and unwanted sensor or atmospheric noise, and converting the data so they accurately represent the reflected or emitted radiation 
Lazarus Abore Mbaya; Spatial Analysis of Gully Erosion Control Measures in Gombe Town, Gombe State Nigeria, Advances in I mage and Video Processing, Volume 4 No 5, August (2017); pp: 17-28

measured by the sensor. Image enhancement is solely to improve the appearance of the imagery to assist in visual interpretation and analysis. The image pre-processing, enhancement and transformation operations are done using ERDAS IMAGINE 9.1. To segregate the study area from the images, geo-referencing of the satellite images have been performed. They are transformed to the Universal Transverse Mercator (UTM) map projection system.

\section{Findings and Discussion}

\subsection{Spatial Distribution of Gully Length in Gombe Town}

Previous studies conducted in Gombe township erosion control and the ministry of environment (2003) on the yearly physical assessment of gully situation after each rainy season shows that the total length of gully within the metropolis is about $121.5 \mathrm{~km}$, out of this only $5.6 \mathrm{~km}$ in length have been controlled while $7.62 \mathrm{~km}$ have been partially controlled leaving about $107.3 \mathrm{~km}$ still uncontrolled, (SEEDS 2006). Comparing the result of the manually digitized gully and ground truth measurements in 2016 shows that most of the previous uncontrolled or partially checked gullies have increased in length to $131.02 \mathrm{~km}$ as against the $121.50 \mathrm{~km}$ in 2003. This represent an increase of $9.72 \mathrm{~km}$ (7.42\%) over the 13 years period or about 75 metres annual increase in gully length, despite various control measures taken by previous and current government (Table I and Fig. 3).

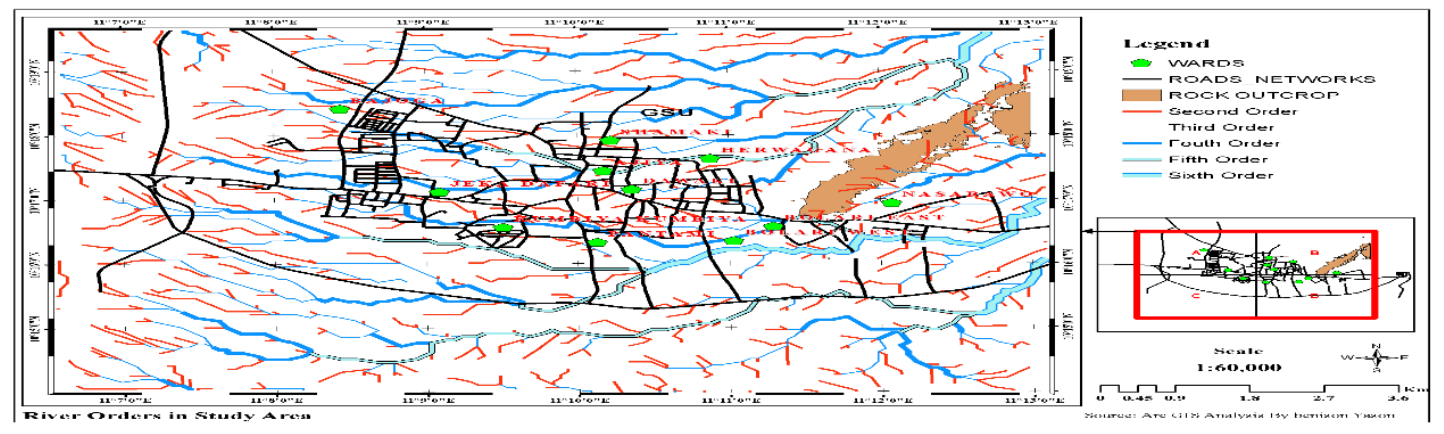

Figure 3: Spatial distribution of gully Erosion in Gombe metropolis. Source: GIS analysis 2016

Table I: Spatial Distribution of Gully Erosion Length in Gombe Town (2003 and 2016)

\begin{tabular}{|l|l|l|l|}
\hline S/No & Name of Gully Sites & \multicolumn{2}{|c|}{ Length in Km } \\
\cline { 3 - 4 } & & 2003 & 2016 \\
\hline 1 & FCE (T) - Arawa & 10.6 & 12.34 \\
\hline 2 & Mallam Inna - Gombe Hill & 4.9 & 4.6 \\
\hline 3 & Mallam Inna - Arawa & 2.20 & 2.85 \\
\hline 4 & Arabic T. C- Mallam Inna & 3.20 & 3.54 \\
\hline 5 & Railway - Mallam Inna & 0.5 & 1.0 \\
\hline 6 & GSU - Railway & 1.50 & 1.50 \\
\hline 7 & FCE (T) staff school - Arabic TC & 3.8 & 4.3 \\
\hline 8 & Musaba clinic - Tudun wada & 1.9 & 1.9 \\
\hline 9 & Ministry of Agric -Tudun wada & 1.1 & 1.1 \\
\hline 10 & Federal lowcost - Dukku motor park & 1.8 & 0.8 \\
\hline 11 & Liman Pri Sch - Mallam Inna & 2.8 & 0.8 \\
\hline 12 & Sabon Fegge - Railway & 2.5 & 3.2 \\
\hline 13 & Govt comp sc Sch - former GSEMA & 2.91 & 3.4 \\
\hline 14 & Railway - Gandu day SC School & 2.92 & 1.5 \\
\hline 15 & Railway - Police barrack & 3.56 & 1.5 \\
\hline 16 & Herwagana - Gombe hill & 4.35 & 3.1 \\
\hline 17 & Bubayero - Herwagana & 1.0 & 1.0 \\
\hline 18 & Dawaki - Herwagana & 0.7 & 0.7 \\
\hline
\end{tabular}




\begin{tabular}{|c|c|c|c|}
\hline 19 & Gombe Line park - Central pr Sch & 0.85 & 0.85 \\
\hline 20 & Old grave yard - Bubayero pr sch & 3.3 & 2.3 \\
\hline 21 & Federal Lowcost - old grave yard & 1.65 & 2.0 \\
\hline 22 & State secretariat - old grave yard & 2.43 & 2.43 \\
\hline 23 & Federal lowcost - Bubayero pr Sch & 1.2 & 1.0 \\
\hline 24 & Jallo waziri pr sch - Kcc Computer & 0.55 & 0.55 \\
\hline 25 & Govt SC Sec sch - Fed lowcost & 1.35 & 0.35 \\
\hline 26 & Railway - AYU Quary & 1.74 & 1.2 \\
\hline 27 & Bogo - Doma & 5.6 & 4.6 \\
\hline 28 & $\mathrm{~J} /$ Fari - Yelenguruza & 6.15 & 4.3 \\
\hline 29 & Shongo estate - Civil service com & 4.7 & 4.4 \\
\hline 30 & Ashaka road-Civil service com & 2.67 & 2.29 \\
\hline 31 & Ahmad Gombe pr sch - J/Fari & 1.36 & 1.36 \\
\hline 32 & Ministry of works $-\mathrm{J} /$ Fari & 0.55 & 0.55 \\
\hline 33 & Liberty - J/Fari & 0.45 & 0.45 \\
\hline 34 & Gombe Int Pr Sch - J/ Fari & 2.23 & 2.23 \\
\hline 35 & Miyetti cinema - Gombe Int sch & 0.5 & 0.5 \\
\hline 36 & Bolari-Gombe chemist & 0.8 & 0.8 \\
\hline 37 & Abubakar memorial pr sch - Y/guruza & 0.6 & 1.3 \\
\hline 38 & Army barrack - Abubakar memorial pr & 1.6 & 2.1 \\
\hline 39 & Gombe High School - U /church & 1.12 & 1.12 \\
\hline 40 & Abuja quarters - Army barrack & 0.15 & 0.15 \\
\hline 41 & GSWC - Army barrack & 0.15 & 0.15 \\
\hline 42 & GRA - GSWC & 2.3 & 1.3 \\
\hline 43 & New GRA - Police commissioner's qt & 2.1 & 2.4 \\
\hline 44 & Police commissioner's quarter - ECWA Good news & 1.0 & 1.0 \\
\hline 45 & Orji quarters - GSWC & 3.1 & 2.1 \\
\hline 46 & Buhari estate - GRA Road & 0.8 & 1.0 \\
\hline 47 & Bamusa - Army Barrack & 2.35 & 2.56 \\
\hline 48 & Bogo - Manawashi & 4.4 & 4.3 \\
\hline 49 & GSADP Quarters - Manawashi & 4.92 & 4.65 \\
\hline 50 & Pantami police station - GSADP & 0.8 & 0.8 \\
\hline 51 & Borehole NO. 94/Manawashi-Madaki & 2.2 & 1.6 \\
\hline 52 & Buhari estate - Borehole No. 94 & 2.65 & 2.87 \\
\hline 53 & Masina - borehole No 94 & 1.05 & 1.0 \\
\hline 54 & Duniya earth dam - Borehole No 94 & 3.85 & 3.4 \\
\hline 55 & Riyad-Burunde & 4.20 & 3.8 \\
\hline 56 & Hammad Kafi-Riyad & 1.65 & 1.9 \\
\hline 57 & Wuro Briji - Riyad & 3.4 & 2.8 \\
\hline 58 & Hammad Kafi - Wuro Briji & 1.92 & 2.6 \\
\hline \multirow[t]{2}{*}{59} & Duniya earth dam - Wuro Briji & 4.25 & 3.78 \\
\hline & Total & 121.50 & 131.02 \\
\hline
\end{tabular}

Source: Gombe State Ministry of Water Resources and Environment (2003) and Field work 201

\subsubsection{Spatial Distribution of Gully / Stream Orders}

The spatial distribution of gully/ streams orders of the study area was extracted from the satellite image. The first order, second, third, fourth and fifth orders are the tributary that contributes to the main gully channel (sixth order) which is less dominant. The analysis revealed that there were 615 first order gullies representing $62 \%$ second order has 173 gullies or $18 \%$, third order gullies has 89 in number and represent $12 \%$, the fourth order has a total of 51 gullies in number representing $5 \%$, the fifth order consist of 30 gullies or $2 \%$ and the sixth order number which is the main gully has 11 in number representing $1.0 \%$ respectively. were the main gullies spread across the study area (Fig. 4). The sixth, fifth and fourth orders are the main stream channel ( gullies) which tends to dominate the 
Lazarus Abore Mbaya; Spatial Analysis of Gully Erosion Control Measures in Gombe Town, Gombe State Nigeria, Advances in Image and Video Processing, Volume 4 No 5, August (2017); pp: 17-28

north-western part with their head incision towards the north eastern parts of the metropolis. This is due to the effect of the topography of over $400 \mathrm{~m}$ above sea level dominating the western parts of the study area.

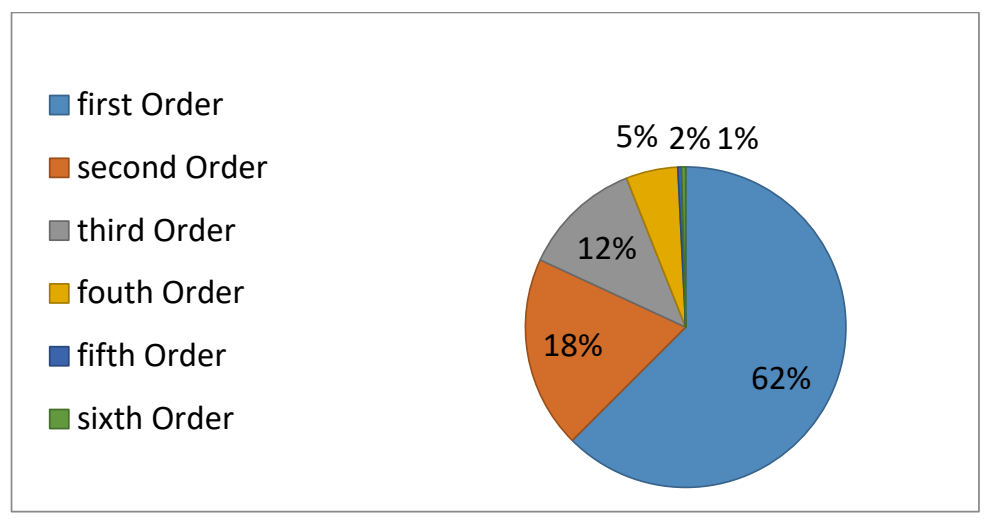

Figure 4: Spatial distribution of gully orders in Gombe Town. Source: GIS Analysis 2016

The first and second order Gullies /stream constituted the most spatially distributed (Table 2) and the most hazardous environmental problems threatening lives, infrastructural development and generally hindering the physical expansion of the town. Furthermore since there are so many governments find it very difficult to control these gullies, hence each rainy season gullies continue to increased in number and size.

Table 2: Distribution of Gully orders Densities in Gombe Town

\begin{tabular}{|c|c|c|c|c|c|c|c|}
\hline \multicolumn{7}{|c|}{ Sampled Quarters/ wards } & \multirow[b]{2}{*}{$\begin{array}{l}\% \\
\text { Total }\end{array}$} \\
\hline $\begin{array}{l}\text { Gully } \\
\text { orders }\end{array}$ & $\begin{array}{l}\text { Fed. Lowcost/ FCE (T) - } \\
\text { Arawa/ M/Inna }\end{array}$ & $\begin{array}{l}\text { Shamaki- GSU } \\
\text { Y/Gana/ } \\
\text { Dawaki/ Bajoga }\end{array}$ & $\begin{array}{l}\text { Kumbi } \\
\text { Kumbiya/ } \\
\text { Bolari. } \\
\text { J/Fari }\end{array}$ & $\begin{array}{l}\text { GRA- } \\
\text { Pantami- } \\
\text { Madaki- } \\
\text { Doma }\end{array}$ & Total & $\begin{array}{l}\text { Mean } \\
\text { Total }\end{array}$ & \\
\hline 1st order & 157.99 & 151.63 & 159.01 & 145.95 & 614.58 & 153.64 & 62 \\
\hline $\begin{array}{l}\text { 2nd } \\
\text { order }\end{array}$ & 49.00 & 42.00 & 43.00 & 39.00 & 173.00 & 43.25 & 18 \\
\hline $\begin{array}{l}\text { 3rd } \\
\text { order }\end{array}$ & 30.57 & 17.82 & 24.22 & 15.89 & 88.50 & 22.12 & 12 \\
\hline $\begin{array}{l}\text { 4th } \\
\text { order }\end{array}$ & 13.21 & 16.08 & 13.60 & 7.80 & 50.68 & 12.67 & 5 \\
\hline $\begin{array}{l}5 \text { th } \\
\text { order }\end{array}$ & 0.96 & 9.86 & 6.92 & 11.54 & 29.29 & 7.32 & 2 \\
\hline $\begin{array}{l}\text { 6th } \\
\text { order }\end{array}$ & 1.03 & 1.47 & 0.50 & 8.20 & 11.20 & 2.80 & 1 \\
\hline TOTAL & 252.75 & 238.86 & 247.26 & 228.38 & 967.25 & 241.81 & 100 \\
\hline
\end{tabular}

Source: GIS analysis/field work 2016 
Table 3: Length of Gullies Orders of Sample Wards each

\begin{tabular}{|l|l|l|l|l|l|}
\hline & \multicolumn{3}{|l|}{ Length of gullies(km) } & \\
\hline $\begin{array}{l}\text { Orders of } \\
\text { stream }\end{array}$ & $\begin{array}{l}\text { Fed. Lowcost/ FCE (T) } \\
- \text { Arawa/ M/Inna }\end{array}$ & $\begin{array}{l}\text { Shamaki- } \begin{array}{l}\text { GSU } \\
\text { Y/Gana/ Dawaki/ } \\
\text { Bajoga }\end{array} \\
\text { Kumbi Kumbiya/ } \\
\text { Bolari. J/Fari }\end{array}$ & $\begin{array}{l}\text { GRA-Pantami- } \\
\text { Madaki- Doma }\end{array}$ & Total \\
\hline $1^{\text {st }}$ order & 10.2 & 9.5 & 6.2 & 4.5 & 30.4 \\
\hline $2^{\text {nd }}$ order & 2.9 & 5.8 & 5.6 & 6.3 & 20.8 \\
\hline $3^{\text {rd } \text { order }}$ & 1.16 & 9.0 & 2.35 & 4.8 & 17.31 \\
\hline $4^{\text {th } \text { order }}$ & 5.9 & 2.3 & 5.5 & 9.36 & 23.0 \\
\hline $5^{\text {th } \text { order }}$ & 4.3 & 5.3 & 4.3 & 4.2 & 18.1 \\
\hline $6^{\text {th } \text { order }}$ & 1.51 & 12 & 0.02 & 8.0 & 20.35 \\
\hline Total & 25.96 & 43.9 & 23.97 & 37.16 & 131.02 \\
\hline
\end{tabular}

Source: GIS analysis/Field work, 2016.

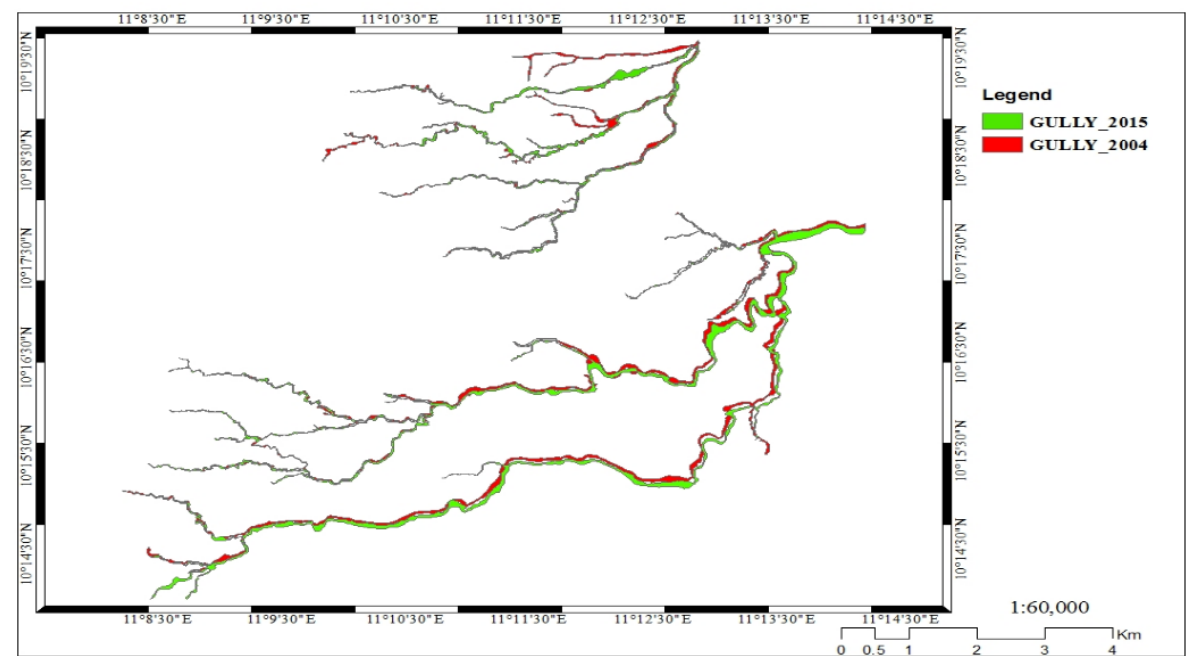

Figure 5: Overlay result of the 2004 and 2015 images of digitized Gully erosion.

Source: GIS analysis/Field work 2015

Using manual digitizing technique and ground truth very small gullies are easily detected visually and mapped thus providing the most accurate results that can be utilized as reference data. The result is differentiated by green and red color indicating gully extent as at 2004 and that of 2015 (Fig 5). Previous studies conducted shows that the total length of gully within the metropolis was about $121.5 \mathrm{~km}$, out of this only $5.6 \mathrm{~km}$ in length have been controlled while $7.62 \mathrm{~km}$ have been partially controlled leaving about $107.3 \mathrm{~km}$ still uncontrolled, SEEDS (2006). The 2015 analysis from satellite image (Quick birds) revealed a total of $131.02 \mathrm{~km}$ increase gully lengths despite various control measure adopted by governments and residents. This is attributed the hydrological, topographical, geotechnical, soil and demographic factors.

\subsection{Types of Spatial Distribution of Gully erosion Control Measures}

\subsubsection{Engineering Methods}

This is the most effective and costly control method of gully erosion in the study area when best practice is adopted and when the full length is executed. Table 4 shows that out of the $131.02 \mathrm{~km}$ length of gully erosion inventory in Gombe town 2015 only $35.92 \mathrm{~km}$ length has been controlled under 
Lazarus Abore Mbaya; Spatial Analysis of Gully Erosion Control Measures in Gombe Town, Gombe State Nigeria, Advances in I mage and Video Processing, Volume 4 No 5, August (2017); pp: 17-28

engineering method representing $27.2 \%$. Comparing the 2003 estimates of $13.22 \mathrm{~km}$, there has been improvement I pn engineering control methods over the years.

Table 4: Spatial Distribution of Gully Erosion Control Measure Types (Length) in Gombe Town.

\begin{tabular}{|c|c|c|c|c|c|}
\hline \multirow[t]{2}{*}{ S/No } & \multirow[t]{2}{*}{ Name of Gully Sites } & \multicolumn{4}{|c|}{ Types of control measures (Length in Kilimetres) } \\
\hline & & Engineering & Vegetation & Stone wall & $\begin{array}{l}\text { Uncontrolled } \\
\text { length }\end{array}$ \\
\hline 1 & FCE (T) - Arawa & - & 0.5 & - & 11.84 \\
\hline 2 & Mallam Inna - Gombe Hill & - & 0.8 & - & 3.8 \\
\hline 3 & Mallam Inna - Arawa & - & 0.2 & - & 2.65 \\
\hline 4 & Arabic T. C- Mallam Inna & - & - & - & 3.54 \\
\hline 5 & Railway - Mallam Inna & - & - & - & 1.0 \\
\hline 6 & GSU - Railway & - & 0.5 & - & 1.0 \\
\hline 7 & FCE (T) staff school - Arabic TC & - & - & - & 4.3 \\
\hline 8 & Musaba clinic - Tudun wada & 1.0 & - & - & 0.9 \\
\hline 9 & Ministry of Agric -Tudunwada & 1.1 & - & - & - \\
\hline 10 & Federal lowcost - Dukku motor park & 0.8 & - & - & - \\
\hline 11 & Liman Pri Sch - Mallam Inna & - & - & - & 0.8 \\
\hline 12 & Sabon Fegge - Railway & - & 0.6 & 0.3 & 2.3 \\
\hline 13 & Govt comp sc Sch - former GSEMA & - & - & - & 3.4 \\
\hline 14 & Railway - Gandu day SC School & 1 & - & - & 0.5 \\
\hline 15 & Railway - Police barrack & 1.2 & - & - & 0.5 \\
\hline 16 & Herwagana - Gombe hill & 1.5 & - & - & 1.6 \\
\hline 17 & Bubayero - Herwagana & 1.0 & - & - & - \\
\hline 18 & Dawaki-Herwagana & 0.7 & - & - & - \\
\hline 19 & Gombe Line park - Central pr Sch & 0.85 & - & - & - \\
\hline 20 & Old grave yard - Bubayero pr sch & 2 & - & - & 0.3 \\
\hline 21 & Federal Lowcost - old grave yard & 2.0 & - & - & - \\
\hline 22 & State secretariat - old grave yard & 1.43 & - & - & 1.0 \\
\hline 23 & Federal lowcost - Bubayero pr Sch & 1.0 & - & - & - \\
\hline 24 & Jallo waziri pr sch - Kcc Computer & 0.55 & - & - & - \\
\hline 25 & Govt SC Sec sch - Fed lowcost & - & - & - & 0.35 \\
\hline 26 & Railway-AYU Quary & - & - & - & 1.2 \\
\hline 27 & Bogo-Doma & 0.5 & 2 & - & 2.1 \\
\hline 28 & $\mathrm{~J} /$ Fari - Yelenguruza & 4 & - & - & 0.3 \\
\hline 29 & Shongo estate-Civil service com & 2.0 & - & - & 2.4 \\
\hline 30 & Ashaka road-Civil service com & - & - & - & 2.29 \\
\hline 31 & Ahmad Gombe pr sch - J/Fari & 0.36 & - & - & 1.0 \\
\hline 32 & Ministry of works $-\mathrm{J} /$ Fari & 0.55 & - & - & - \\
\hline 33 & Liberty - J/Fari & 0.45 & - & - & - \\
\hline 34 & Gombe Int Pr Sch - J/Fari & 2.23 & - & - & - \\
\hline 35 & Miyetti cinema - Gombe Int sch & 0.5 & - & - & - \\
\hline 36 & Bolari-Gombe chemist & 0.8 & - & - & - \\
\hline 37 & Abubakar memorial pr sch - Yelenguruza & - & - & - & 1.3 \\
\hline 38 & Army barrack - Abubakar memorial pr sch & - & - & - & 2.1 \\
\hline 39 & Gombe High School - U Cchurch & 1.0 & - & - & 0.12 \\
\hline 40 & Abuja quarters - Army barrack & - & - & - & 0.15 \\
\hline 41 & GSWC - Army barrack & - & - & - & 1.3 \\
\hline 42 & GRA-GSWC & 2.1 & - & - & 0.3 \\
\hline 43 & New GRA - Police commissioner's quarter & - & - & - & 2.2 \\
\hline 44 & Police commissioner's quarter - ECWA Good news & 1.0 & - & - & - \\
\hline 45 & Orji quarters-GSWC & 2.1 & - & - & - \\
\hline 46 & Buhari estate - GRA Road & 1.0 & - & - & - \\
\hline 47 & Bamusa - Army Barrack & - & - & - & 2.56 \\
\hline 48 & Bogo - Manawashi & - & 0.5 & - & 3.8 \\
\hline 49 & GSADP Quarters - Manawashi & 1.2 & - & - & 3.45 \\
\hline 50 & Pantami police station - GSADP & - & - & - & 0.8 \\
\hline 51 & Borehole NO. 94 - Manawashi - Madaki & - & - & - & 1.6 \\
\hline 52 & Buhari estate - Borehole No. 94 & - & - & - & 2.87 \\
\hline
\end{tabular}




\begin{tabular}{|c|c|c|c|c|c|}
\hline 53 & Masina - borehole No 94 & - & - & - & 1.0 \\
\hline 54 & Duniya earth dam - Borehole No 94 & - & - & - & 3.4 \\
\hline 55 & Riyad-Burunde & - & - & - & 3.8 \\
\hline 56 & Hammad Kafi - Riyad & - & - & - & 1.9 \\
\hline 57 & Wuro Briji - Riyad & - & - & - & 2.8 \\
\hline 58 & Hammad Kafi - Wuro Briji & - & - & - & 2.6 \\
\hline \multirow[t]{2}{*}{59} & Duniya earth dam - Wuro Briji & - & - & - & 3.78 \\
\hline & Total & 35.92 & 5.1 & 0.3 & 90.94 \\
\hline
\end{tabular}

Source: Field work, 2015

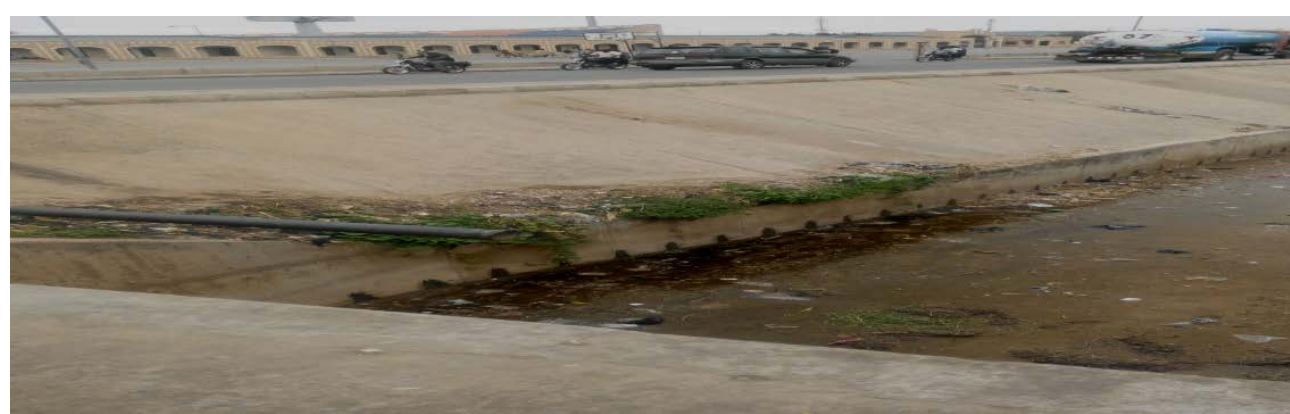

Plate I: Engineering control measure in Pantami ward (stadium) (N 10 $10^{\circ} 16^{\prime} 30.1^{\prime \prime}, \mathrm{E}$ 011 10.02 .5 )

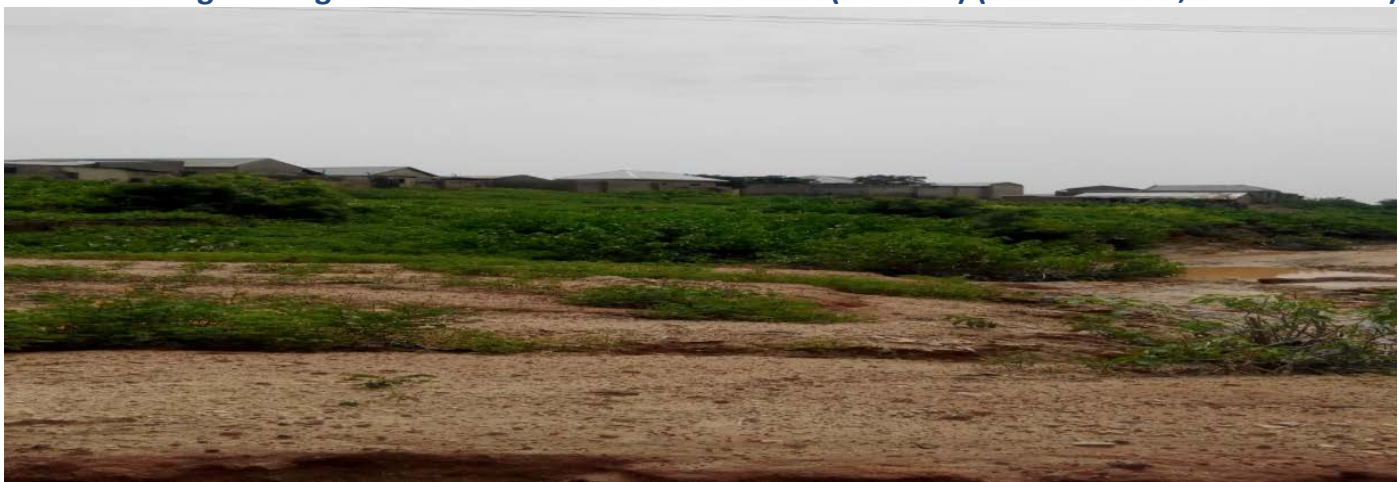

Plate II: Vegetative control meas1ure (Pantami ward, N10 $0^{0} 16^{1} 30.1^{1}, \mathrm{E} 11^{0} 10^{1} 02.5^{11}$ )

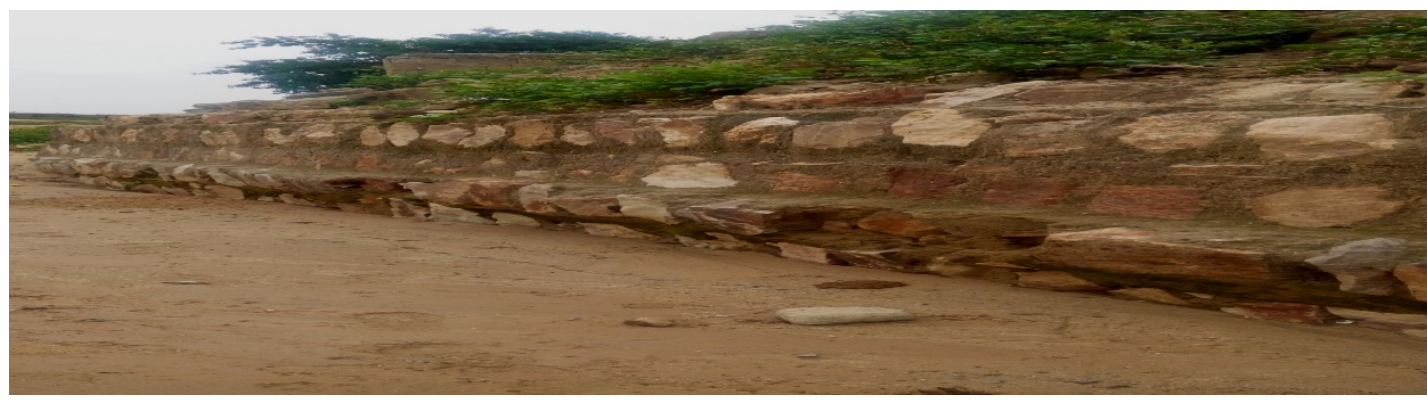

Plate III: Stonewall Control measure (Tundu Wada ward, N 10018.6451, E11 11.5471)

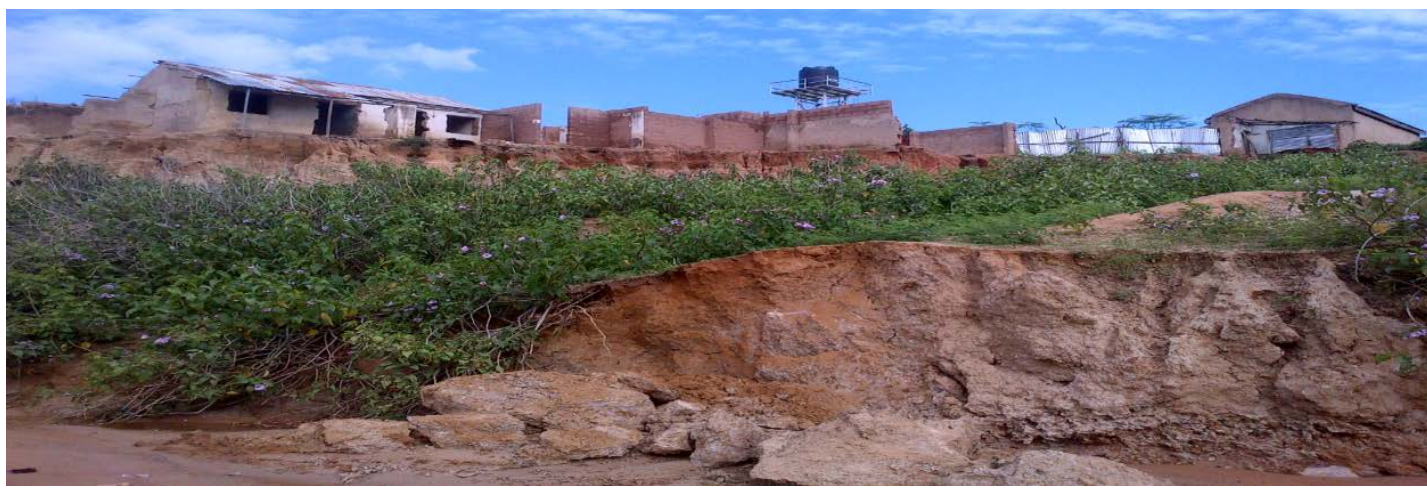

Plate IV: Uncontrolled gully Gully erosion (Arawa, Shamaki ward N10 $10^{1} 37.8^{11} \mathrm{E}^{1} 1^{0} 10^{1} 43.5^{11}$ ) Source: Field work, 2016. 


\subsubsection{Vegetation Method}

The main reason for this success is connected to street/ roads construction which are also accompanied by construction of drainages more especially in Federal lowcost, Kumbiya Kumbiya, Dawaki, Jagada Fari, and shongo estate among others. Table 4 shows only $5.1 \mathrm{~km}$ length of vegetation used in gully erosion control measures out of the total $35.92 \mathrm{~km}$ length of the three methods of control measures under study, representing $14.19 \%$ and $3.89 \%$ of the total lengths of gullies in the study area. The main type of vegetation used is that of paniculatu / Pitadeniastrum africanum (kasha kori). This specie of plant is very effective in controlling gully erosion, as it is prone to dryness, survive throughout year, numerous and fine roots density within $0-60 \mathrm{~cm}$ soil depth, not palatable for animals, affordable and accessible. Unlike engineering method the use of vegetation is cheaper and very fast in stabilizing gully erosion corridors. Most of the areas where vegetation is used are found in low income and sub urban areas where gully erosion menace is devastating and government intervention in terms of engineering method hardly reached. Individual or community efforts contributed to the $5.1 \mathrm{~km}$ length of vegetation planted in affected gully erosion corridors.

\subsubsection{Stone wall method}

Stone wall like engineering method requires capital and technical known how, hence individual or community rarely adopt this method. Table 4 revealed no substantial length $(300 \mathrm{~m})$ of stone wall used in controlling gully erosion in the study area. However, Gombe State Ministry of Water Resources and Environment (2003) reported that stone wall was the earlier method adopted in controlling gully erosion, but most of it has collapsed hence government decision replacing them with engineering method.

\section{Summary and Conclusion}

Result of the study revealed that most of the previous uncontrolled or partially checked gullies have increased in length to $131.02 \mathrm{~km}$ as against the $121.50 \mathrm{~km}$ in 2003. This represents an increase of 9.72 $\mathrm{km}(7.42 \%)$ over the 13 years period or about 75 metres annual increase in gully length. The analysis further revealed that there were 615 first order gullies representing $62 \%$ second order has 173 gullies or $18 \%$, third order gullies has 89 in number and represent $12 \%$, the fourth order has a total of 51 gullies in number representing $5 \%$, the fifth order consist of 30 gullies or $2 \%$ and the sixth order number which is the main gully has 11 in number representing $1.0 \%$ respectively. Out of the 131.02 km length of gully erosion inventory in Gombe town 2015 only $35.92 \mathrm{~km}$ length has been controlled under engineering method representing $87 \%$. On the other hand $5.1 \mathrm{~km}$ length of vegetation used in gully erosion control measures out of the total $41.32 \mathrm{~km}$ length of the three methods of control measures under study.

Gully erosion in Gombe town will continue to do more havoc as long as the various landuses that are in conflict with environment and holistic approach to erosion control measures are not taken. While engineering method of gully erosion control is the best, it is expensive and costly and required technical known how, therefore it is suggested that residents and other stake holders can contribute through planting and rising of vegetation along the gully corridors. Kashe kwari for example is very effective in gully erosion control as it is affordable, accessible, survive and thrive well in the long dry season, not palatable to animals and when matured can be harvested as fuelwood more especially the vulnerable people in the town. 
The loss of lands due to gully erosion and the increasing demand made on the land by agriculture, urban growth, industrialization and other human activities make the need for integrated landscape planning urgent.

Proper land use and watershed management can be used to reduce surface water runoff and control infiltration in order to dampen erosive forces and reduce the erodibility of soils. However, lack of awareness about the cause of the problem is very evident within the community. Many households in the community either do not know the cumulative effect of the lack of proper drainage systems or do not care because there are no direct and immediate repercussions for their poor land management. There is a lack of legislative frameworks to ensure that households refrain from practices that cause gully erosion, and enable these communities enact enforcement mechanisms. In addition, information on the causes of gully erosion and how it can be prevented are scarce. Many of these communities are not aware of the major causes of gully erosion and how it can be prevented, or how their actions are contributing to gully formation but if they are enlighten on the adverse effect of their contribution as well as the significant direct effect of gully erosion then they can have a cautions mind of how to help in monitoring, and even prevent the gully. Below is an efficacy model that should be added to the above in other to bridge the gap for the controlling of gully in the study area.

\section{REFERENCE}

[1] Ananda J and Herath G. (2003)"Soil Erosion in Developing Countries: a Social Economic Appraisal. Pub Med (www.pub med.gov.J.environ managr.2003;68(4):343-53 ELSEVIER.

[2] Arabi, A. S.; Nur, A.; Dewu, B.B.M. (2009) Hydro Geo-Electrical Investigation in Gombe Town and Environs, Northeastern Nigeria Journal of Applied Sciences \& Environmental Management, Vol. 13, No. 3, Sept, 2009, pp. 65-68

[3] Balzerek, H; Werner F,; Jürgen $\mathrm{H}$; , Klaus-martin M and Markus R (2003) Man Made Flood Disaster in the Savanna Town of Gombe/NE Nigeria. In Erdkunde 94-109

[4] Gombe State Ministry of Water Resources and Environment (2003). Gully Erosion Control Master Plan, Pentagon Engineering Nigeria.

[5] Lazarus. A. M, H. k. Ayuba, John Abdullahi (2012) An assessment of Gully erosion in Gombe town Gombe State Nigeria. Journal of Geography and Geology. Page 110-117.

[6] National Population Commission (2007) Census Results. National population commission, Gombe office

[7] Ologe, K. O. (1987) Soil Erosion Characteristics, Processes and Extent in the Nigerian Savanna. In V. O. Sagua, E.E. Enabor, G. E. K. Ofomata, K. O. Ologe, \& L. Oyebande (eds) Ecological Disasters in Nigeria: Soil erosion, 26-49.

[8] Poesen j (2002) "Gully erosion in dryland environment". In Bull, Louise J. \& Kirby, M.J. Dryland Rivers: Hydrology and geomorphology of semi-Arid channels. John wiley \& Sons. ISBN 978-0-471-49123-1.

[9] Poesen, J., (1998) Gully typology and gully control measures in the European loess belt. www.elsevier.com/locate/catena. Down loaded 2/9/2009

[10] Peosen J, Ngehtergaele J, Verstraeten G and Valentin C (2003) "Gully Erosion and Environmental change, importance and Research needs" Catena, Vol 50 pp 91-133. 
Lazarus Abore Mbaya; Spatial Analysis of Gully Erosion Control Measures in Gombe Town, Gombe State

Nigeria, Advances in Image and Video Processing, Volume 4 No 5, August (2017); pp: 17-28

[11] SEEDS (2006). State Economic Empowerment and Development Strategy (SEEDS). Managemen Review limited, Lagos, Nigeria.

[12] Tiffen M (2006). Gombe Emirate,68- 1990; Urban and Commercial development. A public lecture held in Gombe state university $12^{\text {th }}$ February; $1-6$. 